\title{
Reliability of a Brief Intercept Survey for Trail Use Behaviors
}

\author{
Philip J. Troped, Heather A. Whitcomb, Brent Hutto, Julian A. Reed, and Steven P. Hooker
}

Purpose: This study assessed test-retest reliability of an interviewer-administered trail survey. Methods: An intercept survey was conducted with adults using 2 paved trails in Indiana and South Carolina $(\mathrm{N}=295$; mean age $=$ $46.9 \pm 18 \mathrm{y}$ ). The survey included items on frequency and duration of trail use for recreation and transportation, other patterns of trail use, and sociodemographic characteristics. Fiftyfive adults completed the survey twice (2-16 d apart; mean $=7.4 \pm 2.6 \mathrm{~d}$ ). Test-retest reliability was assessed with Spearman rank correlation coefficients, Kappa coefficients, and percent agreement. Results: Kappa coefficients and percent agreement for 9 categorical items ranged from 0.65 to 0.96 and from $64.0 \%$ to $98.2 \%$, respectively. Among these items, the lowest Kappas were found for perceived safety (0.65) and reported duration of visits for recreational purposes (0.67). Spearman rank correlation coefficients for travel distance to and on the trail and frequency of trail use during the past 7 days and past 4 weeks ranged from 0.62 to 0.93. Conclusion: Though further assessments of this survey with different populations and types of trails may be warranted, its overall high reliability indicates it can be used by researchers and practitioners in its current form.

Keywords: trails, physical activity, exercise, built environment

Physical inactivity continues to be a significant public health problem in the United States. ${ }^{1,2}$ There is growing recognition that modifying population levels of physical activity requires an ecological framework that incorporates environmental and policy-level strategies. ${ }^{3}$

Troped and Whitcomb are with the Dept of Health \& Kinesiology, Purdue University, West Lafayette, IN. Hutto and Hooker are with the Prevention Research Center, University of South Carolina, Columbia, SC. Reed is with the Dept of Health and Exercise Science, Furman University, Greenville, SC.
Systematic reviews of physical activity intervention studies conducted by the Task Force on Community Preventive Services resulted in recommendations for 3 approaches that focus on aspects of the built environment. 4,5 One of these is the "creation of or enhanced access to community facilities combined with informational outreach."5

Community trails are a specific component of the built environment that fit this recommendation. Researchers have attempted to identify correlates of trail use $^{6}$ and the potential impact of trails on community physical activity and walking levels. ${ }^{7-9}$ Several recently published studies used objective methods such as infrared counters to assess trail use ${ }^{10-12}$ however, most trailrelated research has been conducted with surveys (eg, mail, phone, and trail intercepts). Collecting trail use data with objective methods is likely to continue; however, it is also likely that trail surveys will continue to be feasible options for both researchers and practitioners. Surveys have limitations, such as recall errors and response biases due to perceptions about socially desirable responses; ${ }^{13,14}$ therefore, an initial assessment of the reliability of these instruments is essential. The primary aim of this study was to assess the test-retest reliability of an interviewer-administered trail intercept survey.

\section{Methods}

\section{Participants and Setting}

Adults using a trail located in West Lafayette, Indiana, and one in Columbia, South Carolina, were recruited for this study. The Cattail Trail in West Lafayette is 4.3 miles long and approximately 10 feet wide. It is connected to another local trail, is part of a planned network of trails, and is adjacent to a nature center, a commercial retail center, and several multifamily residential housing areas. The Three Rivers Greenway, located across the Congaree River from the western boundary of Columbia, is 3 miles long and 8 feet wide. This greenway connects to another trail, follows the shore of the Congaree River, and has amenities for fishing, canoeing, picnicking, and mountain biking. Both trails are paved, multipurpose trails, and have parking lots adjacent to access points. 


\section{Data Collection}

The Committee on the Use of Human Research Subjects at Purdue University and the Institutional Review Board at the University of South Carolina (USC) approved study procedures. Surveys were conducted during the late spring of 2007. Interviewers positioned themselves at 1 location on each trail and signs were posted nearby to alert trail users to the survey. In an effort to obtain a representative sample, time of day and day of the week (weekday, weekend) for data collection were systematically varied. The test-retest period ranged between 2 and 16 days (mean $=7.4 \pm 2.6$ days).

Interviewers asked the first adult trail user $(\geq 18$ years of age) passing the intercept location if they were willing to participate in a brief survey. Once the survey was completed, the interviewer approached the next trail user passing the location. If the interviewer was unsure about the trail user's age, he/she would confirm the person was at least 18 years old before conducting the survey. A script was used to describe the purpose of the study, inform the person of their rights as a research participant, and explain the confidential nature of the information to be provided. Verbal informed consent was obtained from participants. After completing the survey, participants were informed that research staff would be on the trail the following week. These respondents were encouraged to participate in the survey a second time in exchange for a music download card worth $\$ 3$.

\section{Trail Intercept Survey}

The trail survey was a 17-item instrument that took about 5 minutes to complete. It was designed to be a flexible survey that would allow practitioners and researchers to collect information at various types of paved and unpaved community multiuse trails (eg, railtrails, loops within parks, etc.) and from a wide variety of trail users (eg, recreational, transportation). Some items were based on a previous survey developed by our group..$^{6,15}$

\section{Data Processing}

Surveys were conducted in the field using a paper form. Research staff reviewed all surveys for completeness and consistency of responses and legibility. Epi Info (Version 3.4) (http://www.cdc.gov/epiinfo/) was used for data entry. All surveys were double entered.

\section{Statistical Analysis}

Univariate statistics (eg, means, frequencies) were used to summarize responses for the full study sample (ie, adults who completed the survey once and those who completed it twice; $\mathrm{N}=295$ ) and separately for Indiana $(\mathrm{n}=209)$ and South Carolina $(\mathrm{n}=86)$ participants. In addition, we compared the reliability sample $(n=55)$ to adults who completed the survey 1 time $(n=240)$ on select sociodemographic and trail use variables using chi-square statistics and 2-sample $t$ tests.

Test-retest reliability for categorical survey items was assessed with percentage of observed agreement and Kappa coefficients. Adjectival ratings for Kappa coefficients based on Landis and Koch's classification ${ }^{16}$ are also presented. To assess reliability of continuous survey items, we used Spearman rank correlation coefficients for nonnormally distributed data. All analyses were conducted with SAS 9.1.

\section{Results}

\section{Characteristics of Participants}

Survey participants at the 2 trails were similar in terms of gender and race/ethnicity, while Indiana trail users had a much higher proportion of graduate and doctoral degrees (data not shown). Overall, 55\% of participants were female, $71.2 \%$ earned a college degree or higher, $97.7 \%$ were non-Hispanic and $91.8 \%$ were white. The average age was $46.9 \pm 18$ years. The test-retest reliability sample $(n=55)$ did not show statistically significant differences from trail users that completed the survey once $(n=240)$ in terms of gender, educational level, race or ethnicity. However, the reliability sample was older $(52.3 \pm 19.2$ years versus $45.6 \pm 17.5$ years, respectively; $P \leq .01)$. Participants in the reliability sample also used the trail more frequently and accessed the trail differently than participants that responded to the survey 1 time only (Table 1 ).

\section{Reliability of Survey Items}

Overall, reliability of categorical items ranged from "substantial" to "almost perfect" by the Landis and Koch $^{16}$ criteria with Kappa coefficients between 0.65 and 0.96 and observed agreement between $64 \%$ and $98 \%$ (Table 1). The exception was 1 question about the change in activity since starting to use the trail which had "fair" reliability $(k=0.35)$. Two items with slightly lower Kappa coefficients were duration questions; the amount of time it took to travel to the trail from home $(k$ $=0.72$ ) and the amount of time spent on the trail for exercise or recreation purposes $(k=0.67)$. Spearman rank correlation coefficients ranged from 0.62 to 0.93 . Of note, the reliability for self-reported frequency of trail use within the past 7 days $(r=.62)$ was less than that found for frequency of use within the past 4 weeks $(r=.85)$. Reliability results are not reported for the transportation-related survey items due to the small sample responding to these items $(\mathrm{n}<10)$.

\section{Patterns of Trail Use}

A majority of trail users had used the trail for at least 1 year, typically accessed the trail from home, and could travel to the trail in less than 15-minutes (Table 1). 
Table 1 Test-Retest Reliability of Trail Intercept Survey Items and Comparison of One-Time Respondents $(n=240)$ and Test-Retest Reliability Sample $(n=55)$

\begin{tabular}{|c|c|c|c|c|}
\hline Survey item & $\begin{array}{l}\text { One-time } \\
\text { respondents } \\
(n=240)\end{array}$ & $\begin{array}{l}\text { Test-retest } \\
\text { respondents } \\
\quad(n=55)\end{array}$ & $\begin{array}{l}\% \text { Observed } \\
\text { agreement }\end{array}$ & $\begin{array}{c}\text { Kappa } \\
\text { coefficient } \\
\text { (adjectival } \\
\text { rating) }\end{array}$ \\
\hline When was the first time you used this trail? ${ }^{\mathrm{a}}$ & & & 89.1 & $\begin{array}{l}0.86(\text { almost } \\
\text { perfect })\end{array}$ \\
\hline 3 months or less & $17(7.1 \%)$ & $3(5.5 \%)$ & & \\
\hline 4-11 months & $32(13.3 \%)$ & $3(5.5 \%)$ & & \\
\hline $1-3$ years & $88(36.7 \%)$ & $26(47.2 \%)$ & & \\
\hline More than 3 years ago & $103(42.9 \%)$ & $23(41.8 \%)$ & & \\
\hline $\begin{array}{l}\text { Where are you usually coming from when you use } \\
\text { this trail? }\end{array}$ & & & 98.2 & $\begin{array}{l}0.95 \text { (almost } \\
\text { perfect) }\end{array}$ \\
\hline Home & $192(80.0 \%)$ & $48(87.3 \%)$ & & \\
\hline Work & $27(11.3 \%)$ & $4(7.3 \%)$ & & \\
\hline Both home and work & $12(5.0 \%)$ & $3(5.5 \%)$ & & \\
\hline Other & $9(3.8 \%)$ & $0(0.0 \%)$ & & \\
\hline $\begin{array}{l}\text { How much time does it usually take you to get to } \\
\text { this trail from your home? }\end{array}$ & & & 92.0 & $\begin{array}{l}0.72(\text { sub- } \\
\text { stantial) }\end{array}$ \\
\hline Less than 15 minutes & $173(85.2 \%)$ & $41(82.0 \%)$ & & \\
\hline $15-29$ minutes & $17(8.4 \%)$ & $6(12.0 \%)$ & & \\
\hline 30 minutes or more & $13(6.4 \%)$ & $3(6.0 \%)$ & & \\
\hline How do you usually get to this trail? ${ }^{\text {a }}$ & & & 96.4 & $\begin{array}{l}0.96 \text { (almost } \\
\text { perfect) }\end{array}$ \\
\hline Car or motor vehicle & $129(54.2 \%)$ & $23(41.8 \%)$ & & \\
\hline Walk & $43(18.1 \%)$ & $20(36.4 \%)$ & & \\
\hline Bicycle & $43(18.1 \%)$ & $11(20.0 \%)$ & & \\
\hline Jog or run & $23(9.7 \%)$ & $1(1.8 \%)$ & & \\
\hline Other & $0(0.0 \%)$ & $0(0.0 \%)$ & & \\
\hline What is your usual reason for using this trail? & & & 94.6 & $\begin{array}{l}0.80 \text { (almost } \\
\text { perfect) }\end{array}$ \\
\hline To exercise or do recreational activity & $221(92.1 \%)$ & $48(87.3 \%)$ & & \\
\hline To travel somewhere & $7(2.9 \%)$ & $3(5.5 \%)$ & & \\
\hline Both for recreation and transportation purposes & $12(5.0 \%)$ & $4(7.3 \%)$ & & \\
\hline $\begin{array}{l}\text { What type of activity do you usually do when you } \\
\text { are on this trail for recreational purposes? }\end{array}$ & & & 96.2 & $\begin{array}{l}0.95 \text { (almost } \\
\text { perfect) }\end{array}$ \\
\hline Walk & $130(55.8 \%)$ & $38(73.1 \%)$ & & \\
\hline Jog or run & $54(23.2 \%)$ & $4(7.7 \%)$ & & \\
\hline Bicycle & $44(18.9 \%)$ & $10(19.2 \%)$ & & \\
\hline Other & $5(2.1 \%)$ & $0(0.0 \%)$ & & \\
\hline $\begin{array}{l}\text { How much time do you usually spend on this trail } \\
\text { per visit when you use it for recreational purposes? }\end{array}$ & & & 64.0 & $\begin{array}{l}0.67(\text { sub- } \\
\text { stantial) }\end{array}$ \\
\hline Less than 30 minutes & $31(13.3 \%)$ & $5(9.8 \%)$ & & \\
\hline 30-44 minutes & $60(25.6 \%)$ & $14(27.5 \%)$ & & \\
\hline $45-59$ minutes & $66(28.3 \%)$ & $11(21.6 \%)$ & & \\
\hline $1-2$ hours & $71(30.5 \%)$ & $17(33.3 \%)$ & & \\
\hline More than 2 hours & $5(2.1 \%)$ & $4(7.8 \%)$ & & \\
\hline
\end{tabular}




\begin{tabular}{|c|c|c|c|c|}
\hline Survey item & $\begin{array}{l}\text { One-time } \\
\text { respondents } \\
(n=240)\end{array}$ & $\begin{array}{l}\text { Test-retest } \\
\text { respondents } \\
(\mathrm{n}=55)\end{array}$ & $\begin{array}{l}\% \text { Observed } \\
\text { agreement }\end{array}$ & $\begin{array}{c}\text { Kappa } \\
\text { coefficient } \\
\text { (adjectival } \\
\text { rating) }\end{array}$ \\
\hline $\begin{array}{l}\text { Are you (walking, biking, etc) more, less, or the } \\
\text { same since you began using this trail? }^{\text {a }}\end{array}$ & & & 72.7 & 0.35 (fair) \\
\hline More & $131(54.6 \%)$ & $36(65.5 \%)$ & & \\
\hline Same or less & $107(44.5 \%)$ & $19(34.5 \%)$ & & \\
\hline $\begin{array}{l}\text { In your opinion, is the maintenance of the trail } \\
\text { excellent, good, fair, or poor? }^{\text {a }}\end{array}$ & & & 94.5 & $\begin{array}{l}0.85 \text { (almost } \\
\text { perfect) }\end{array}$ \\
\hline Excellent & $182(75.8 \%)$ & $42(76.4 \%)$ & & \\
\hline Good & $54(22.5 \%)$ & $13(23.6 \%)$ & & \\
\hline Fair or poor & $4(1.6 \%)$ & $0(0.0 \%)$ & & \\
\hline $\begin{array}{l}\text { In your opinion, is the safety and security along the } \\
\text { trail excellent, good, fair, or poor? }\end{array}$ & & & 78.0 & $\begin{array}{l}0.65 \text { (sub- } \\
\text { stantial) }\end{array}$ \\
\hline Excellent & $114(47.7 \%)$ & $30(54.6 \%)$ & & \\
\hline Good & $105(43.9 \%)$ & $17(30.9 \%)$ & & \\
\hline Fair or poor & $9(3.8 \%)$ & $5(9.1 \%)$ & & \\
\hline Do not know & $11(4.6 \%)$ & $3(5.5 \%)$ & & \\
\hline Continuous survey items & Mean (SD) & Mean (SD) & $\begin{array}{l}\text { Spearman } \\
\text { rank } \\
\text { correlation } \\
\text { coefficient } \\
\text { (r) }\end{array}$ & $P$-value \\
\hline $\begin{array}{l}\text { How far do you usually go to get to this trail from } \\
\text { home (in miles)? }\end{array}$ & $3.77(6.79)$ & $2.93(4.30)$ & 0.93 & $<0.0001$ \\
\hline $\begin{array}{l}\text { About how far do you usually go when you use this } \\
\text { trail for recreation (in miles)? }\end{array}$ & $3.63(2.51)$ & $3.44(2.35)$ & 0.87 & $<0.0001$ \\
\hline $\begin{array}{l}\text { During the past } 7 \text { days (including today), how many } \\
\text { days have you used this trail for recreational pur- } \\
\text { poses (exercise, leisure time)?* }\end{array}$ & $2.49(1.63)$ & $4.00(1.94)$ & 0.62 & $<0.0001$ \\
\hline $\begin{array}{l}\text { During the past } 4 \text { weeks (including today), how } \\
\text { many days have you used this trail for recreational } \\
\text { purposes (exercise, leisure time)?* }\end{array}$ & $8.75(7.11)$ & $14.29(8.07)$ & 0.85 & $<0.0001$ \\
\hline
\end{tabular}

Note. Sample sizes vary by item due to either missing responses or nonapplicable survey items.

a Response categories shown are collapsed from original categories due to either no responses or a small number of responses for a specific category.

* Test-retest respondents significantly different from one-time respondents at the $P<.05$ level.

Overall, about $52 \%$ of trail users drove to the trail, however a much higher percentage of Indiana trail users walked, bicycled, or ran to the trail than did the South Carolina users. Most respondents used the trail only for recreation or exercise, although $12.5 \%$ of trail users in Indiana $(n=26)$ used the trail for transportation or a combination of recreation and transportation. The most common types of activity for recreational purposes were walking and bicycling at the Indiana trail and walking and jogging/running in South Carolina. More than $80 \%$ of trail users that use the trails for recreation or exercise reported spending at least 30 minutes on the trail. Frequency of trail use for recreation averaged almost 3 days during the past 7 days and approximately 10 days during the past 4 weeks.

\section{Discussion}

Given the fact that use of trails is a growing area of research with important implications for physical activity promotion on a population-level, it is important to use survey instruments with sound psychometric properties. This study, which focused on assessing reliability of items in a brief interviewer-administered intercept survey, represents an initial step in this process. Reliable surveys are needed to support the efforts of trail advocates, trail developers, and parks and recreation managers.

Overall, this study found that the majority of items evaluated had relatively high test-retest reliability. A majority of categorical items had Kappa coeffi- 
cients described as "almost perfect," and 3 other items were rated as "substantial." Two items with lower reliability required respondents to estimate the time it took to get to the trail and the duration of physical activity on the trail. As others have noted, recall of physical activity behaviors is a complex task and asking individuals to report on the duration of activity adds to the challenge of obtaining accurate recall. ${ }^{17} \mathrm{In}$ general, our reliability findings compare favorably with a recent study that examined test-retest reliability of physical activity items in the Behavioral Risk Factor Surveillance System, ${ }^{18}$ an Australian reliability study of recreational and transportation physical activity items linked to neighborhood contexts and destinations, ${ }^{19}$ and a New Zealand study of transportation physical activity items. ${ }^{20}$

One of the strengths of the current study is that it assesses a tool that enables the collection of more detailed information about trail users than that provided by direct observation methods (eg, trail user counts). The study is also strengthened by the inclusion of users from similarly constructed trails (ie, paved, multiuse) in 2 states that varied slightly in how they were accessed and used. This contributes somewhat to the generalizability of the findings for multiuse trail users. In terms of limitations, the small reliability sample $(\mathrm{n}=55)$ did not allow us to conduct separate analyses for men and women. Participants were predominantly white and therefore, the findings may not be generalizable to racial and ethnic minority groups. Another limitation is that it is likely that adults who use the trails less often and both bicyclists and runners were under-represented in our reliability sample. Anecdotally, bicyclists and runners appeared to be more reluctant to interrupt their activity to complete a survey. It is unclear how this limitation could have affected the results, though it does indicate the challenges of conducting trail intercept surveys. A final limitation is that no survey participants in South Carolina and only a small number of adults in Indiana were using the trail for transportation. The small sample precluded us from reporting on the reliability of transportation-related items.

It is likely that use of community trails will continue to be a strong area of interest for practitioners and researchers within public health, parks and recreation, and transportation, who will likely continue to use intercept surveys due to their relative low cost and ease of use. As demonstrated in this study, 1 trail survey with generally good reliability is now available.

\section{Acknowledgments}

This research was supported by funding from the College of Liberal Arts, Purdue University. We thank Kosuke Tamura at Purdue University for his edits on versions of this manuscript and Colleen Thompson, David Beiser, and Melissa Markofski at Purdue University and Anna Mathews and Andrea Morrison at the University of South Carolina for conducting surveys.

\section{References}

1. Brown WJ, Burton NW, Rowan PJ. Updating the evidence on physical activity and health in women. Am J Prev Med. 2007;33(5):404-411.

2. Hallal PC, Victora CG, Azevedo MR, Wells JC. Adolescent physical activity and health: a systematic review. Sports Med. 2006;36(12):1019-1030.

3. McLeroy KR, Bibeau D, Steckler A, Glanz K. An ecological perspective on health promotion programs. Health Educ Q. 1988;15(4):351-377.

4. Heath GW, Brownson RC, Kruger J, et al. The effectiveness of environmental and policy interventions to increase physical activity: a systematic review. J Phys Activity Health. 2006;3(Supp 1).

5. Kahn EB, Ramsey LT, Brownson RC, et al. The effectiveness of interventions to increase physical activity. A systematic review. Am J Prev Med. 2002;22(4, Suppl):73-107.

6. Troped PJ, Saunders RP, Pate RR, et al. Associations between self-reported and objective physical environmental factors and use of a community rail-trail. Prev Med. 2001;32(2):191-200.

7. Brownson RC, Housemann RA, Brown DR, et al. Promoting physical activity in rural communities: walking trail access, use, and effects. Am J Prev Med. 2000;18(3):235-241.

8. Evenson KR, Herring AH, Huston SL. Evaluating change in physical activity with the building of a multi-use trail. Am J Prev Med. 2005;28(2, Suppl 2):177-185.

9. Merom D, Bauman A, Vita P, Close G. An environmental intervention to promote walking and cycling-the impact of a newly constructed Rail Trail in Western Sydney. Prev Med. 2003;36(2):235-242.

10. Lindsey G, Han Y, Wilson J, Yang J. Neighborhood correlates of trail use. J Phys Act Health. 2006;3(Suppl 1):S139-S157.

11. Lindsey G, Nguyen DBL. Use of greenway trails in Indiana. J Urban Plann Dev. 2004;130(4):213-217.

12. Lindsey G, Wilson J, Rubchinskaya E, Yang J, Han Y. Estimating urban trail traffic: Methods for existing and proposed trails. Landsc Urban Plan. 2007;81:299-315.

13. Sallis JF, Saelens BE. Assessment of physical activity by self-report: status, limitations, and future directions. Res Q Exerc Sport. 2000;71(2, Suppl):S1-S14.

14. Sirard JR, Pate RR. Physical activity assessment in children and adolescents. Sports Med. 2001;31(6):439-454.

15. Troped PJ, Saunders RP, Pate RR. Comparisons between rail-trail users and nonusers and men and women's patterns of use in a suburban community. J Phys Act Health. 2005;2:169-180.

16. Landis JR, Koch GG. The measurement of observer agreement for categorical data. Biometrics. 1977;33(1):159174.

17. Brener ND, Billy JO, Grady WR. Assessment of factors affecting the validity of self-reported health-risk behavior among adolescents: evidence from the scientific literature. J Adolesc Health. 2003;33(6):436-457. 
18. Yore MM, Ham SA, Ainsworth BE, et al. Reliability and validity of the instrument used in BRFSS to assess physical activity. Med Sci Sports Exerc. 2007;39(8):12671274.

19. Giles-Corti B, Timperio A, Cutt H, et al. Development of a reliable measure of walking within and outside the local neighborhood: RESIDE's Neighborhood Physical Activity Questionnaire. Prev Med. 2006;42(6):455-459.
20. Badland H, Schofield G. Test-retest reliability of a survey to measure transport-related physical activity in adults. Res Q Exerc Sport. 2006;77(3):386-390. 